\title{
PENGARUH METODE CIRCUIT TERHADAP DAYA TAHAN AEROBIK PADA SISWA DI SMA NEGERI 9 OGAN KOMERING ULU
}

\author{
Reza Resah Pratama1, Wahyu Indra Bayu² \\ 1,2 Pendidikan Jasmani dan Kesehatan FKIP Universitas Sriwijaya \\ Email: rezarpunsri@gmail.com¹ wahyu.indra@fkip.unsri.ac.id² \\ DOI: https://doi.org/10.36526/kejaora.v4i2.706
}

\begin{abstract}
ABSTRAK
Penelitian ini bertujuan untuk mengetahui pengaruh metode circuit terhadap daya tahan aerobik pada siswa SMA Negeri 9 OKU. Populasi penelitin ini seluruh siswa SMA Negeri 9 OKU. Purposive sampling digunakan dalam menentukan sampel penelitian, yaitu peserta didik yang mengikuti ekstrakurikuler olahraga di SMA Negeri 9 OKU. Jumlah sampel sebanyak 40 peserta didik. Penelitian ini menggunakan metode eksperimen dengan design quasy eksperimental bentuk one grup pretestposttest design. Data diambil dari tes awal (pretest) dan tes akhir (posttest). Hasil pretest diperoleh bleef test level tertinggi 15,01 dan bleef test level terendah 8,01 sedangkan hasil posstest diperoleh bleef test level tertinggi 16,12 dan bleef test level terendah 9,12. Hasil penelitian pada pretest di peroleh rata-rata 10,6962 dan hasil rata-rata posttest 13,2847. Hasil pretest dan posttest di dapati peningkatan perbedaan rata-rata 2,5885. Berdasarkan analisis penelitian didapat Thitung $(24,942)$ dan Ttabel $(2,045)$. Implikasi penelitian ini metode sircuit dapat meningkatkan daya tahan aerobik pada siswa SMA Negeri 9 OKU, dengan demikian penelitian ini berpengaruh pada daya tahan aerobik.
\end{abstract}

Kata kunci: Metode, Sircuit, Daya Tahan, aerobik

\section{PENDAHULUAN}

Kesegaran jasmani merupakan kemampuan seseorang untuk melakukan suatu pekerjaan tertentu dengan cukup baik, tanpa mengakibatkan kelelahan (Widiastuti,2017:13). Secara umum yang dimaksud kesegaran jasmani adalah kesegaran fisik (physical fitness), dan untuk dapat mencapai kondisi kesegaran jasmani yang prima seseorang perlu melakukan latihan fisik yang melibatkan komponen kesegaran jasmani dengan metode latihan yang benar. $\mathrm{VO}_{2} \mathrm{Max}$ merupakan daya tangkap aerobic maksimal yang menganggambarkan jumlah oksigen maksimum yang dikonsumsi persatuan waktu oleh seseorang selama latihan atau tes. Wuest \& Bucher, (2009) mengenai kesegaran jasmani, mereka mendefinisikan kesegaran jasmani sebagai kemampuan sistem tubuh untuk berfungsi secara efektif dan efisien. Kesegaran jasmani memiliki beberapa komponen. Komponen-komponen tersebut dapat dikelompokkan dalam dua aspek, yaitu (1) kesegaran jasmani yang berhubungan dengan kesehatan; dan (2) kesegaran jasmani yang berhubungan dengan aspek keterampilan (Hastie \& Martin, 2006; Pangrazi \& Beighle, 2010). Untuk komponen kesegaran jasmani yang berhubungan dengan kesehatan terdiri dari komposisi tubuh (body composition), daya tahan kardiorespirasi (cardiorespiratory endurance), kelentukan (flexibility), daya tahan otot (muscular endurance), dan kekuatan otot (muscular strenght). Sedangkan komponen kesegaran jasmani yang berhubungan dengan aspek keterampilan adalah ketangkasan (agility), keseimbangan (balance), koordinasi (coordination), kekuatan (power), kecepatan (speed), dan kecepatan reaksi (reaction time), (Wuest \& Bucher, 2009; Lacy, 2011).

Hasil observasi di SMA Negeri 9

OKU peneliti mengamati populasi yang berjumlah 201 siswa dari jumlah populasi 60 siswa sudah memiliki daya tahan aerobik yang sudah baik, 41 siswa memliki daya tahan aerobic yang cukup baik, 50 siswa sudah memiliki daya tahan aerobik sedang, 
40 siswa memiliki daya tahan aerobic yang buruk atau kurang maksimal, 11 siswa tidak memiliki daya tahan aerobic atau sangat buruk, dari seluruh data siswa SMA Negeri 9 OKU peneliti mangambil sampel 40 siswa yang mengikuti kegiatan ekstrakurikuler. Rendahnya kegiatan latihan-latihan untuk meningkatkan kesegaran jasmani siswa yang kurang maksimal, maka dari permasalahan tersebut pada saat melakukan latihan-latihan fisik dalam melaksanakan kegiatan olahraga siswa cepat mengalami kelelahan, akibat dari kelelahan asupan oksigen ke otot berkurang karena kerja jantung yang memompa darah ke seluruh tubuh dan paru-paru sebagai alat respirasi tidak bekerja maksimal. Maka dapat di simpulkan bahwa daya tahan aerobik siswa di SMA Negeri 9 OKU masih rendah.

Oleh karena itu, melihat kondisi tersebut peneliti ingin mencoba menggunakan metode circuit untuk meningkatkan daya tahan aerobik siswa di SMA Negeri 9 OKU. Hidayat (2014:64) menyatakan bahwa latihan sircuit merupakan sistem latihan yang latihan yang dapat memperkembangkan secara serempak fitness keseluruhan tubuh, yaitu komponen power, daya tahan, kecepatan, fleksibelitas, dan komponen-komponen fisik lainnya.

\section{METODE}

Metode yang digunakan dalam penelitian ini menggunakan metode eksperimen dengan jenis quasy experimental dengan menggunakan one group pretestposttest design untuk mencari pengaruh perlakuan tertentu terhadap yang lain dalam kondisi yang terkendalikan. Populasi penelitian ini sebanyak 40 siswa di SMA Negeri 9 OKU, Seluruh sampel melakukan tes awal (pretest) sebelum diberikan perlakukan setelah itu seluruh sampel di berikan perlakuan yaitu dengan metode circuit setelah diberi perlakuan selama 6 minggu dengan 18 kali pertemuan sampel akan melakukan posttest. Pengukuran daya tahan aerobic mengginakan Multistage Fitness Test (MFT). Untuk menganalisis data hasil penelitian dengan menggunakan paired sample t-test $(p<0,05)$.

\section{HASIL}

Berdasarkan hasil pretest bleep test level tertinggi 15,01, level terendah 8,01 dan ratarata hasil pretest 10,696. Setelah pengambilan hasil data pretest sampel diberi perlakuan dengan metode latihan circuit selama 6 minggu dengan frekuensi latihan 3 kali seminggu, setelah diberi perlakuan selama 6 minggu akan dilakukan tes kembali yang disebut dengan posttest, hasil posttest dengan level tertinggi 16,12 , level terendah 9,12 dan rata-rata hasil posttest 13,285 , setelah di bandingkan hasil dari pretest dan posttest terjadi peningkatan 2,589.

Tabel 1. Hasil Penelitian

\begin{tabular}{cccccc}
\hline Kelompok & $\mathrm{N}$ & Nilai Maksimal & Nilai Minimal & Rata-Rata & Peningkatan \\
\hline Pretest & 40 & 15,01 & 8,01 & 10,69 & 2,58 \\
Posttest & 40 & 16,12 & 9,12 & 13,28 &
\end{tabular}

\section{PEMBAHASAN}

Setelah dibandingkan hasil dari pretest dan posttest terjadi peningkatan 2,589 penelitian ini menunjukkan bahwa metode sirkuit meningkatkan daya tahan aerobic siswa SMA Negeri 9 OKU. Menurut Husdarta dan Maryani (2010) metode latihan sirkuit merupakan latihan yang efektif untuk meningkatkan kebugaran jasmani secara menyeluruh. Pernyataan ini dapat dilihat pada peningkatan rata-rata yang terjadi dari pretest ke posttest setelah diberi perlakuan metode sirkuit selama 6 minggu meningkat sebesar
2,589. terjadinya peningkatan daya tahan aerobik pada siswa SMA Negeri 9 OKU karena diberikan metode latihan sirkuit secara berulang, hal ini sependapat dengan Apta \& Kurniawan (2015) peningkatan latihan akan terjadi apabila seseorang melakukan latihan secara berulang-ulang dengan jangka waktu yang panjang.

Latihan yang digunakan untuk meningkatkan hasil daya tahan aerobik adalah metode sicuit. penelitian ini menggunakan sampel 40 siswa. 40 sampel ini dijadikan satu kelompok ekperimen yang 
akan dites terlebih dahulu sebelum diberi perlakuan (pretest) untuk mengetahui data hasil siswa sebelum melakukan metode sirkuit setelah itu sampel diberikan perlakuan dengan metode sirkuit selama 6 minggu. Husdarta dan Maryani (2010) Latihan ini merupakan latihan yang efektif untuk meningkatkan kebugaran jasmani secara menyeluruh. Dengan frekuensi latihan 3 kali seminggu dan intensitas latihan $40 \%-60 \%$ dan 3-5 set setelah 6 minggu latihan metode sirkuit. sampel penelitian melakukan tes kembali (posttest). latihan dalam pengertian fisiologis adalah suatu perbaikan sistem dan fungsi organ dalam tugasnya untuk mewujudkan suatu prestasi atlet serta latihan merupakan proses kerja yang harus dilakukan secara sistematis dan berulang (lyakrus 2012). Sebelum data pretest atau posttest dilakukan uji normalitas dan hasil yang di dapat sebagai berikut: nilai signifikan yang diperoleh $(p)(0,23)>a(0,05)$, lalu data posttest didapati nilai signifikan yang diperoleh $(p)(0,04)>a(0,05)$. Hasil ini menunjukkan data pretest dan posttest berdistribusi normal karena nilai signifikan yang diperoleh lebih besar dari taraf signifikan uji (a) $(0,05)$. Hal ini sesuai dengan kriteria penetapan kenormalan menurut Gunawan (2013) yang mengatakan jika signifikasi yang diperoleh ( $p$ ) >a, maka sampel tersebut berasal dari populasi yang berdistribusi normal. Setelah mengetahui data berdistribusi normal, uji hipotesis pun dapat dilakukan dengan menggunakan uji-t berpasangan dengan bantuan aplikasi SPSS. Hasil uji-t yang didapati adalah Thitung $(24,942)>$ Ttabel $(2,045)$ dan nilai sig. ( $p)$ $0,000<$ dari 0,05 , hasil ini menunjukkan adanya perbedaan yang signifikan antara pretest dan posttest. Dari hasil tersebut juga menunjukkan bahwa hipotesis yang diterima atau Ha yaitu "Ada Pengaruh Metode circuit Terhadap Daya Tahan Aerobik Pada Siswa SMA Negeri 9 OKU". Hasil analisis seluruh data memberikan jawaban terhadap permasalahan yang diajukan dalam penelitian ini. Berdasarkan dari hasil data yang didapat bahwa metode sircuit memberikan pengaruh yang signifikan terhadap hasil daya tahan aerobic pada siswa SMA Negeri 9 OKU. Dilihat dari beberapa pendapat diatas dan hasil hipotesis yang diterima maka peneliti dapat menyimpulkan bahwa metode sircuit berpengaruh terhadap daya tahan aerobik yang dilihat dari data pretest dan posttest, peningkatan terjadi setelah diberi perlakuan yaitu metode latihan sirkuit selama 6 minggu sesuai dengan intensitasnya yang meningkat.

\section{KESIMPULAN}

Berdasarkan hasil penelitian, maka dapat disimpulkan bahwa metode circuit berpengaruh terhadap daya tahan aerobic. Latihan yang dilakukan secara sistematis, berulang, dan bersikenambungan dengan beban yang semakin meningkat membuat sistem tubuh semakin pulih hingga akan berpengaruh pada peningkatan fisik, dengan semakin meningkatnya daya tahan karena faktor yang diterapkan maka kemampuan akan meningkat oleh karena itu bentuk metode sirkuit yang di terapkan pada sampel mengalami peningkatan karena efisiennya latihan yang dilakukan.

\section{DAFTAR PUSTAKA}

Apta, M. \& Kurniawan, F. 2015. IImu Kepelatihan Dasar Bandung: Alfabeta.

Gunawan, M.A. 2013. Statistik untuk Penelitian Pendidikan.Yogyakarta: Parama Publishing

Hastie, P.A. \& Martin, E.H. 2006. Teaching Elementary Physical Education: Strategies for the Classroom Teacher. San Francisco: Benjamin Cummings, Pearson Education, Inc.

Hidayat, S. 2014. Pelatihan Yogyakarta: Graha Ilmu

Olahraga.

lyakrus, 2012. Penerapan Closed Skill dan Open Skill dalam Latihan Sepak Takraw di Penjas FKIP Universitas Sriwijaya. Jurnal IImu Olahraga dan Kesehatan. 2(1): 1-6.

Lacy, A.C. 2011. Measurement and Evaluation in Physical Education and Exercise Science (6 $6^{\text {th }}$ Edition). San Francico: Pearson Benjamin.

Pangrazi, R.P., \& Beighle, A. 2010. Dynamic Physical Education for Elementary School Children (16 th Edition). San Francisco: Benjamin Cummings, Pearson Education, Inc.

Husdarta, J.S. \& Maryani, E. 2010. Pendidikan Jasmani Olahraga dan 
Jurnal Kejaora, Volume 4 Nomor 2, November 2019, ISSN 2541-5042

Kesehatan. Jakarta: PT. Masmedia

Buana Pustaka.

Sukirno. 2012. Kesehatan Olahraga, Doping dan Kesegaran Jasmani. Palembang: Unsri Press.

Widiastuti. 2017. Tes dan Pengukuran Olahraga. Jakarta: PT. Raja Grafindo.

Wuest, D.A. \& Bucher, C.A. 2009. Foundation of Physical Education, Exercise Science, and Sport (16 th Edition). New York: McGraw Hill. 